\title{
Viral hepatitis and hepatitis $B$ antigen: recent advances
}

\author{
SAUL KRUgman \\ M.D. \\ Department of Pediatrics, New York University, School of Medicine, New York, N.Y.
}

\begin{abstract}
Summary
Recent advances in hepatitis research have shed new light on the etiology, pathogenesis, epidemiology and prevention of type $B$ hepatitis infection. The so-called 'Dane' particle is probably the complete hepatitis B virion; its outer coat is the hepatitis B (Australia) antigen (HB Ag) and its inner core is an immunologically distinct particle. Subtypes of $\mathrm{HB} \mathrm{Ag}(\mathrm{a}, \mathrm{d}, \mathrm{y}, \mathrm{w}$ and $\mathbf{r})$ are useful indices for epidemiological surveys. Concepts of epidemiology have changed: type B hepatitis is transmissible by contact as well as by inoculation. The presence of $\mathrm{HB} \mathrm{Ag}$ in blood is indicative of the presence of hepatitis $B$ virus. Tests to detect antigen and use of voluntary blood donors have played a major role in the decreased incidence of post transfusion hepatitis. A special hepatitis B gammaglobulin preparation and a heat-inactivated hepatitis $B$ vaccine have proved to be effective in preliminary studies.
\end{abstract}

THE term viral hepatitis refers to two immunologically distinct entities: type $A$ (infectious) hepatitis and type $\mathbf{B}$ (serum) hepatitis. Viral hepatitis, type $\mathbf{A}$ is an ancient disease which was described by Hippocrates as an 'infectious icterus' more than 2000 years ago. In contrast, type $B$ hepatitis has a more recent history since the first outbreak was recognized in 1883 , less than 100 years ago (Lürman, 1885).

Evidence for the viral etiology of hepatitis stems in great part from investigations by MacCallum and Bradley in the United Kingdom (1944), Havens et al. (1944), Paul et al.(1945), and Neefe et al. (1945) in the United States in the early 1940s. They identified the two immunologically distinct types of hepatitis which were designated type $\mathbf{A}$ and type $B$. These observations were extended by Murray et al. (1955) in the early 1950s and by our group in the late 1950s and 1960s (Ward et al., 1958; Krugman et al., 1959, 1962, 1967).

Our studies were conducted in a large institution for mentally retarded residents where hepatitis was highly endemic. During the course of these studies we had an opportunity to observe patients with hepatitis from the time of exposure, during the incubation period, after onset of jaundice or abnormal serum transaminase activity, and for many years thereafter. The serial samples of serum which were obtained provided valuable materials for the characterization of the clinical, epidemiological and immunological aspects of the infection. The background of this investigation is described in detail in previous publications (Krugman et al., 1959, 1962, 1967, 1970).

In the mid 1960s it became obvious that two types of hepatitis were endemic in the institution. One type, designated MS-1, resembled typical viral hepatitis, type A; it had a relatively short incubation period. The other type, MS-2, was associated with a longer incubation period and it resembled viral hepatitis, type B. It was observed that in this long incubation period, hepatitis infection was transmissible by mouth and by contact as well as by inoculation. The differential features of MS-1 and MS-2 types of hepatitis are shown in Fig. 1 and Table 1.

The discovery of Australia antigen (Blumberg et al., 1965) and its association with hepatitis B virus infection (Prince, 1968; Krugman et al., 1970) provided the technology needed to further clarify the natural history of hepatitis. During a seminar on viral hepatitis in Paris in 1971, Dr John F. Enders highlighted this important development when he said: 'After a long and arid period, a new and exhilarating phase in the study of hepatitis has begun. The discovery of Australia antigen came like an unexpected shower on desert soil'.

In a recent report, a WHO Scientific group (1973) proposed that Australia antigen be referred to as hepatitis $\mathrm{B}$ antigen ( $\mathrm{HB} \mathrm{Ag}$ ) and the corresponding antibody as hepatitis B antibody (HB Ab). This recommendation was based on the evidence that the antigen had a specific association with hepatitis B virus. Therefore, the term 'Australia' could be misleading because of the implication of an association with that country. The term hepatitis-associated antigen (HAA) was used before the specificity of the antigen for type B hepatitis was proved.

\section{Hepatitis $B$ antigen}

The nature of $\mathrm{HB} \mathrm{Ag}$ has been described in detail in several excellent reviews by Professor Zuckerman 


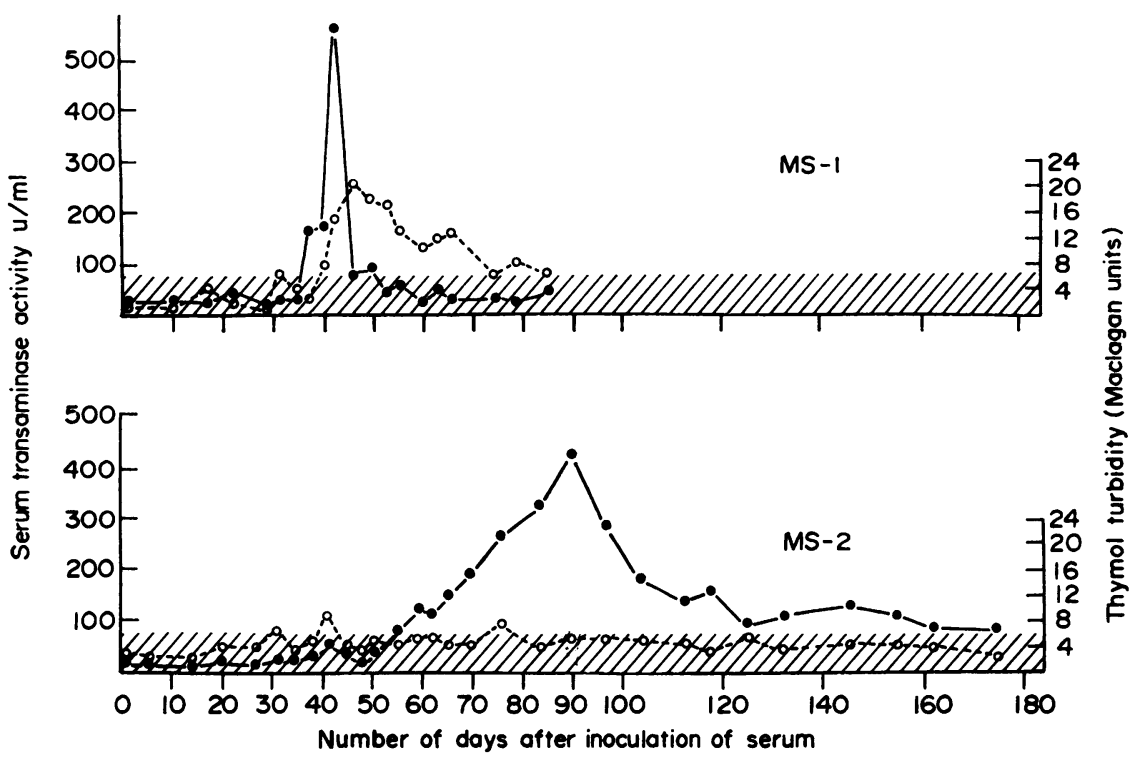

FIG. 1. Serum glutamic oxaloacetic transaminase (SGOT) and thymol turbidity (TT) response following exposure to hepatitis A virus (MS-1 strain) and hepatitis B virus (MS-2 strain). Jaundice when present is observed at time of peak SGOT level. - , SGOT; - - -, TT.

Table 1. Viral hepatitis, types A and B: Clinical epidemiological and immunological features compared

\begin{tabular}{|c|c|c|}
\hline & Type A & Type B \\
\hline Incubation period & $15-40$ days & 50-180 days \\
\hline Type of onset & Usually acute & Usually insidious \\
\hline Fever & Common-precedes jaundice & Less common \\
\hline Age group affected & $\begin{array}{l}\text { Usually children and young } \\
\text { adults }\end{array}$ & All age groups \\
\hline Jaundice & $\begin{array}{l}\text { Rare in children; more } \\
\text { common in adults }\end{array}$ & $\begin{array}{l}\text { Rare in children; more common in } \\
\text { adults }\end{array}$ \\
\hline Abnormal SGOT & Transient-1-3 weeks & More prolonged $-1-8+$ months \\
\hline Thymol turbidity & Usually increased & Usually normal \\
\hline IgM levels & Usually increased & Usually normal \\
\hline $\begin{array}{l}\text { HB Ag (Australia } \\
\text { antigen in blood) }\end{array}$ & Not present & $\begin{array}{l}\text { Present in incubation period and acute } \\
\text { phase; occasionally may persist }\end{array}$ \\
\hline Virus in faeces & $\begin{array}{l}\text { Present during late incubation } \\
\text { period and acute phase }\end{array}$ & Probably present but no direct proof \\
\hline Virus in blood & $\begin{array}{l}\text { Present during late incubation } \\
\text { period and early acute phase }\end{array}$ & $\begin{array}{l}\text { Present during late incubation period } \\
\text { and acute phase; occasionally } \\
\text { present for months and years }\end{array}$ \\
\hline \multicolumn{3}{|l|}{ Immunity } \\
\hline $\begin{array}{l}\text { Homologous } \\
\text { Heterologous }\end{array}$ & $\begin{array}{l}\text { Present } \\
\text { None }\end{array}$ & $\begin{array}{l}\text { Present } \\
\text { None }\end{array}$ \\
\hline
\end{tabular}

(1971, 1972), a participant at this meeting. Briefly, it is a lipoprotein, immunologically distinct from beta lipoproteins. Electronmicroscopic examination of serum containing the antigen has revealed evidence of the following types of virus-like particles: (1) spherical particles, $20 \mathrm{~nm}$ in diameter; (2) elongated particles, 100 or more $\mathrm{nm}$ long and $20 \mathrm{~nm}$ in diameter; and (3) the so-called 'Dane particles' which are $42 \mathrm{~nm}$ in diameter, consisting of an outer coat and an inner core (Dane, Cameron and Briggs, 1970).
It has been postulated that the 'Dane particle' is the complete hepatitis B virion and the smaller $20 \mathrm{~nm}$ particles represent excess virus-coat material or incomplete particles.

Subspecificities of HB Ag have been described by LeBouvier $(1971,1972)$. He and other workers have observed a common group specificity for the antigen which has been designated ' $a$ ', and two mutually exclusive subspecificities, ' $d$ ' and ' $y$ '. Two additional determinants, ' $w$ ' and ' $r$ ' were described by Bancroft, 
Mundon and Russell (1972). The 'd' and ' $y$ ' determinants reflect the genotype of $\mathrm{HB} \mathrm{Ag}$ and therefore they are useful indices in epidemiological surveys.

Studies of the inner component of the $42 \mathrm{~nm}$ particle by Almeida, Rubenstein and Stott (1971) are being extended by other investigators who are attempting to characterize the biophysical and antigenic composition of the core. Their findings should further define the features of the etiologic agent of viral hepatitis, type B.

\section{Epidemiological aspects of type $B$ hepatitis}

Until recent years it was assumed that hepatitis $B$ virus (HBV) was transmissible exclusively by parenteral inoculation. However, concepts of the epidemiology of viral hepatitis, type B have changed significantly since 1967 . It is now clear that non-parenteral transmission of HBV plays an important role in the spread of the disease.

Healthy chronic carriers and patients with acute or chronic hepatitis are the chief sources of the virus. The infection is transmitted to susceptible persons by transfusion of contaminated blood, blood-products, needles and syringes. Accidental inoculation or ingestion of infectious materials may occur in health workers. In areas of the world where primitive sanitary conditions exist, the infection is spread by contact.

Seroepidemiological surveys for the presence of $\mathrm{HB} \mathrm{Ag}$ and $\mathrm{HB} \mathrm{Ab}$ have confirmed the existence of the disease in all parts of the world. The disease is most prevalent among populations living under conditions of poor sanitation and crowding.

The period of infectivity of patients with viral hepatitis, type $B$ is variable; it is dependent upon the presence or absence of a chronic carrier state.
Hepatitis B antigen may be detected in the blood 2 weeks to 2 months before onset of hepatitis. In most patients the antigen is no longer detectable from several days before to about 3 months after onset of jaundice.

The detection of $\mathrm{HB} \mathrm{Ag}$ in blood is indicative of the presence of infectious HBV. However, tests for HB Ag may not be sensitive enough to detect small amounts of antigen which may be present in blood containing HBV. Therefore, a negative test for $\mathrm{HB} \mathrm{Ag}$ does not rule out the presence of virus. Under these circumstances HB Ag-negative blood could cause viral hepatitis, type $\mathbf{B}$.

\section{Clinical aspects of viral hepatitis}

Prospective observations of the clinical course of viral hepatitis have revealed differences between type A and type B infection. As indicated in Fig. 1 and Table 1 , type $A$ infection is characterized by a shorter incubation period and a shorter duration of abnormal serum transaminase activity. Our prospective studies have revealed that $\mathrm{HB} \mathrm{Ag}$ is not present in the serum of patients with viral hepatitis, type $A$; it is consistently detected some time during the course of viral hepatitis, type B. The antigen was not detected in serial samples of serum obtained from forty patients with type A hepatitis. In contrast, HB Ag was detected in forty-nine of fifty patients with type $B$ hepatitis.

The serum specimens from the one patient who had no detectable HB Ag by immunodiffusion and complement fixation were retested for antigen by radioimmunoassay. This more sensitive test revealed the presence of $\mathrm{HB} \mathrm{Ag}$ in a specimen obtained several days before the SGOT became abnormal.

The variable course of hepatitis B virus infection

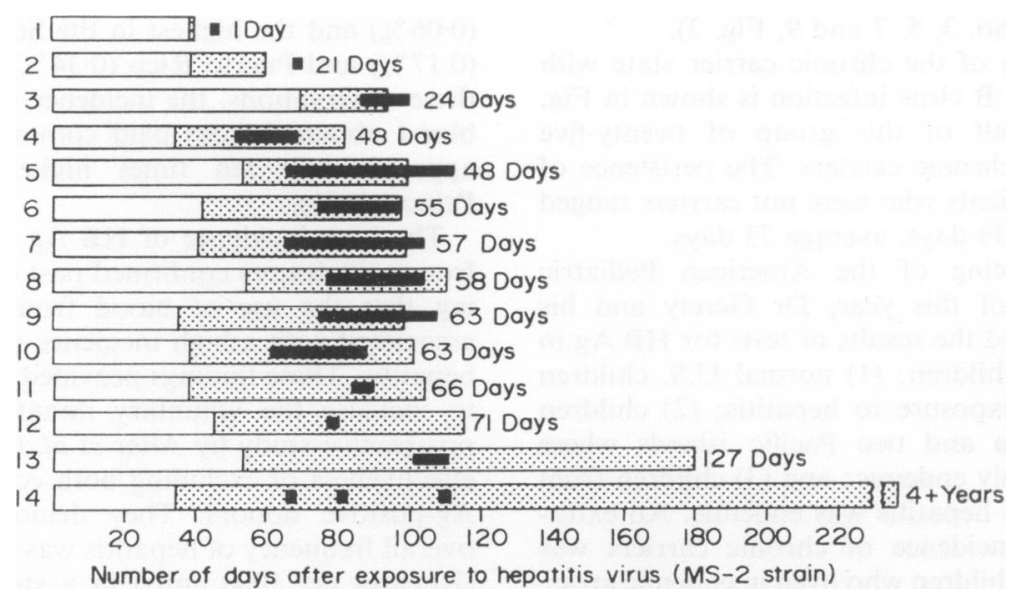

FIG. 2. Serial observations of fourteen patients with icteric viral hepatitis, type B. Stippled areas indicate $\mathrm{HB}-\mathrm{Ag}$ detectable in blood. Black bars indicate presence of jaundice. Duration of antigenaemia in patients no. 1-13 ranged between 1 day and 127 days. 


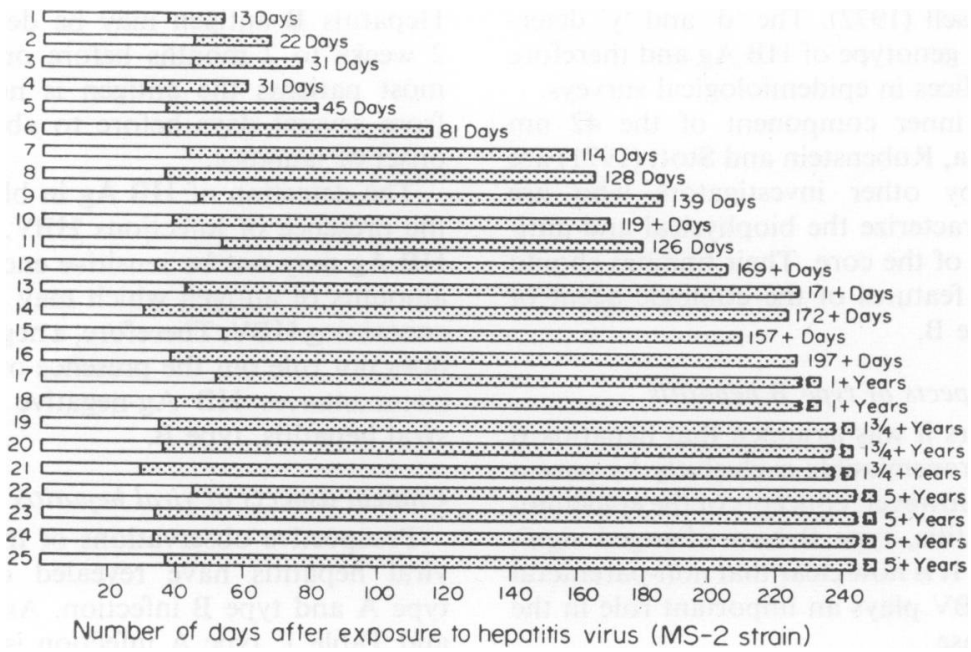

FIG. 3. Serial observations of twenty-five patients with anicteric viral hepatitis, type B. Stippled areas indicate $\mathrm{HB}$ Ag detectable in blood. Note high incidence of chronic carrier state.

is illustrated in Figs. 2 and 3. As indicated in Fig. 2, the carrier state was rarely observed in patients with icteric hepatitis $B$ virus infection. Of fourteen patients followed prospectively only one was a carrier. Serial observations of the remaining thirteen patients revealed that $\mathrm{HB}$ Ag was detectable for an average of 54 days; the range was 1-127 days. Antigen was consistently detected before onset of jaundice. Occasionally HB Ag became non-detectable before onset of jaundice (patients no. 1 and 2 in Fig. 2). In general, HB Ag persisted for several days or weeks after subsidence of jaundice (patients no. 4, 8, 10, 11, 12 and 13, Fig. 3). However, in some instances the jaundice persisted longer than the antigen (patients no. 3, 5, 7 and 9, Fig. 2).

The association of the chronic carrier state with anicteric hepatitis B virus infection is shown in Fig. 3. More than half of this group of twenty-five patients became chronic carriers. The peristence of $\mathrm{HB} \mathrm{Ag}$ in ten patients who were not carriers ranged between 13 and 139 days, average 73 days.

During a meeting of the American Pediatric Society in May of this year, Dr Gerety and his colleagues reported the results of tests for $\mathrm{HB} \mathrm{Ag}$ in three groups of children: (1) normal U.S. children with no known exposure to hepatitis; (2) children from West Africa and two Pacific islands where hepatitis was highly endemic; and (3) children from institutions where hepatitis was endemic. An extraordinarily high incidence of chronic carriers was observed among children who lived in endemic areas.

\section{Hepatitis $B$ antigen and post-transfusion hepatitis}

When it became apparent that the detection of
HB Ag was indicative of the presence of hepatitis B virus, the routine testing of donor blood was instituted. Since 1970 many millions of units of blood have been screened for HB Ag. Great varia tions in the prevalence of $\mathrm{HB} \mathrm{Ag}$ in presumable healthy blood donors have been found in different parts of the world. The prevalence of the antigen has been shown to be related to such factors as socioeconomic status and whether the blood is obtained from a volunteer or paid donor.

The overall incidence of HB Ag in volunteer blood donors in the United States is $0.15 \%$ (Szmuness et al., 1973). Regional variations have been observed, the lowest incidence being in the North Central States $(0.06 \%)$ and the highest in the South-eastern States $(0.17 \%)$ and Puerto Rico $(0.34 \%)$. In contrast with these observations, the incidence of $\mathrm{HB} \mathrm{Ag}$-positive blood obtained from paid commercial donors was $\delta$ approximately ten times higher (Cherubin and Prince, 1971).

The high incidence of $\mathrm{HB} \mathrm{Ag}$ in blood obtained from paid donors confirmed past experience indicating that the use of blood from this source was associated with a high incidence of post-transfusion $\sigma$ hepatitis. These findings provided an added stimulus $N$ to increase the voluntary donations of blood. A prospective study by Alter et al. (1972) revealed the effectiveness of excluding both commercial and $\mathrm{HB}_{\odot}$ Ag-positive donors. They demonstrated that the overall frequency of hepatitis was reduced from $33 \% \stackrel{\text { ? }}{?}$ (20 cases per 1000 units) in a study conducted be- $\square$ tween 1967 and 1969 , to $7 \cdot 1 \%$ (3.7 cases per 1000 웅 units) in a more recent study in 1970 and 1971. An $\stackrel{\mathbb{D}}{\mathscr{D}}$ $82 \%$ decrease in the hepatitis rate was achieved. In $\underset{\mathbb{Q}}{\stackrel{2}{2}}$ 
the first study many patients received commercial blood at a time when HB Ag testing was not done. In the second study both commercial donors and HB Ag-positive donors were excluded. Alter et al. (1972) have estimated that the substitution of $\mathrm{HB}$ Ag-negative for HB Ag-positive blood while continuing the use of commercial blood would have decreased the $33 \%$ rate of hepatitis to $25 \%$, a reduction of $25 \%$. The exclusion of commercial donors, however, would have decreased the rate from $33 \%$ to $10 \%$, a reduction of $70 \%$.

Studies by various investigators are currently in progress to determine the effect of the presence of hepatitis B antibody in donor blood. Such antibody was found in $10-40 \%$ of adults when sensitive techniques were employed for its detection. Preliminary reports by Gocke and Panick (1972) and by Caggiano (1972) indicated that the transfusion of HB Ab-positive blood was not associated with an increased risk of post-transfusion hepatitis.

To date, the routine screening of blood for the presence of $\mathrm{HB} \mathrm{Ag}$ has played an important role in the control of post-transfusion hepatitis. The testing of blood has had a direct effect by identifying potentially infectious units of blood. The indirect effect has been more important because the results of the test have confirmed the increased risk of using blood from commercial donors. The limitations of the test for $\mathrm{HB} \mathrm{Ag}$ have been twofold: (1) lack of sensitivity to detect all infectious units of blood; and (2) identification of only one of various causes of post-transfusion hepatitis; others include hepatitis A virus, cytomegalovirus and EB (Epstein-Barr) virus.

The advent of more sensitive tests for the detection of HB Ag should have a beneficial, though not highly significant effect on the incidence of post-transfusion hepatitis. Since most healthy carriers have a relatively high titre of circulating $\mathrm{HB} \mathrm{Ag}$, only a small number of additional carriers will be discovered by the use of radioimmunoassay and other highly sensitive tests. Further reduction in the incidence of posttransfusion hepatitis will require the development of a biological test for the detection of hepatitis B virus. The ultimate control of viral hepatitis types $A$ and $B$ will depend in great part on the development of effective active and passive immunization procedures.

\section{Prospects for prevention of viral heptatitis, types A and $B$ \\ Passive immunization}

Viral hepatitis, type A. The efficacy of standard immune serum globulin for the prevention or modification of type A hepatitis has been well documented. The results of controlled studies by many investigators during the past 30 years have confirmed the value of this passive protection when the gamma globulin is given shortly after exposure to a known contact.

Viral hepatitis, type $B$. The efficacy of standard immune serum globulin for the prevention of type B hepatitis has been a controversial subject for many years. Reports of its value have varied from limited protection to none at all. This phenomenon is due in part to the fact that most lots of standard gammaglobulin have non-detectable or low levels of HB Ab.

The preparation of specific hepatitis $B$ immune serum globulin from plasma containing high levels of $\mathrm{HB} \mathrm{Ab}$ provided a preparation with an antibody titre which was $25,000-50,000$ times higher than the standard licensed product (Prince et al., 1971). The preliminary trials reported by our group (Krugman et al., 1971) and by Soulier et al. (1972) revealed that the use of this specific globulin was associated with a protective effect, an attenuated infection, when present, and a decreased chronic carrier rate. At the present time the National Institutes of Health and the Veterans Administration are conducting a nationwide trial to evaluate the efficacy of this special gammaglobulin preparation. It is anticipated that the results of these studies will be available by 1975 .

\section{Active immunization}

Viral hepatitis, type A. Failure to cultivate hepatitis A virus or to identify an antigen associated with it has retarded the development of an active immunizing agent. However, the confirmatory reports of the successful propagation of hepatitis A virus in marmoset monkeys are encouraging.

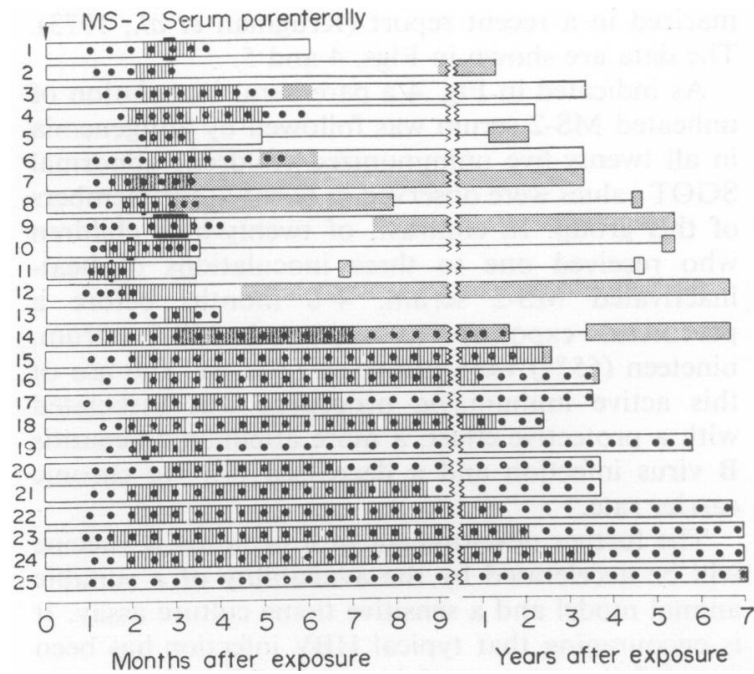

FIG. 4. Course of hepatitis B virus infection (MS-2 strain) in twenty-five unimmunized children after a parenteral exposure to MS-2 serum. Black dots, HB Ag; vertical lines, SGOT abnormal; shaded area, anti-HB $\mathrm{Ag}$; black bars, jaundice. 

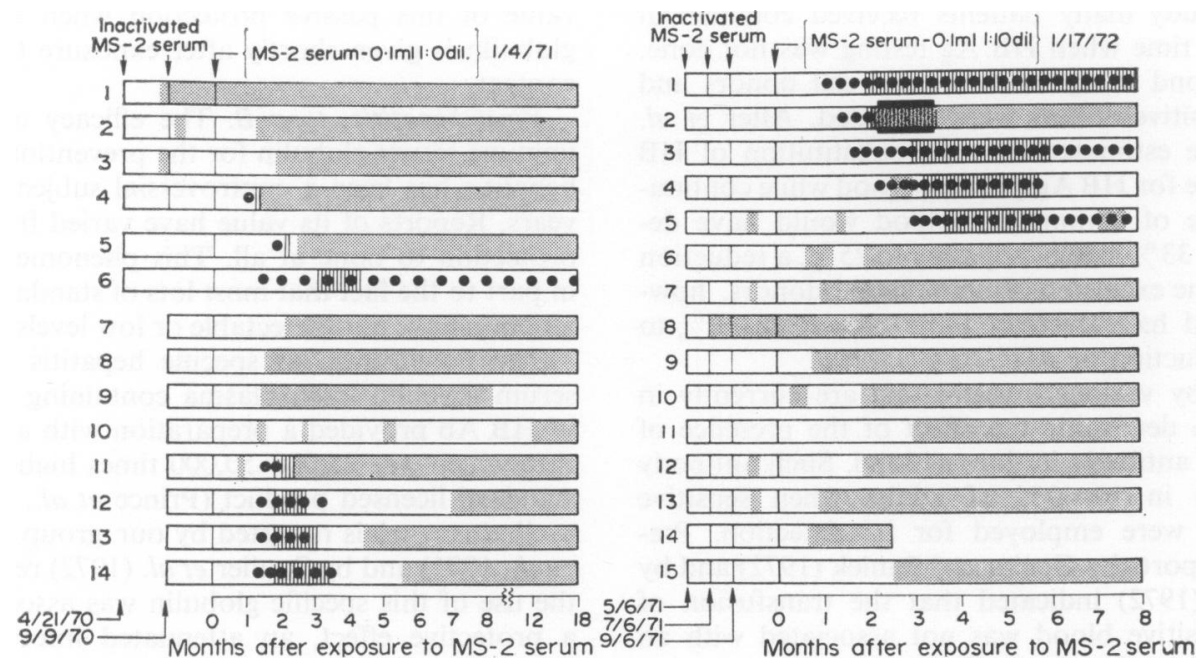

FIg. 5. Active immunization with heat-inactivated MS-2 serum. Note (1) protective effect; (2) evidence of an attenuated infection; and (3) a decreased chronic carrier rate in these immunized children when compared with the unimmunized group (Fig. 4). Black dots, HB Ag; vertical lines, SGOT abnormal; shaded area, anti-HB $\mathrm{Ag}$; black bars, jaundice.

Viral hepatitis, type $B$. The development and use of active immunizing procedures have been reported by our group (Krugman et al., 1971a, b) and Soulier et al. (1972). Serum containing our MS-2 strain of HBV was diluted in distilled water and heated for $1 \mathrm{~min}$ at $98^{\circ} \mathrm{C}$. The heat-treated serum proved to be antigenic and non-infectious. The results of active immunization of twenty-nine children were summarized in a recent report (Krugman et al., 1973). The data are shown in Figs. 4 and 5.

As indicated in Fig. 4 a parenteral inoculation of unheated MS-2 serum was followed by antigenemia in all twenty-five unimmunized children; abnormal SGOT values were observed in twenty-four members of this group. In contrast, of twenty-nine children who received one to three inoculations of heatinactivated MS-2 serum, 4-8 months before a parenteral exposure to unheated MS-2 serum, nineteen $(65 \%)$ were protected (Fig. 5). The use of this active immunizing procedure was associated with a protective effect, a more attenuated hepatitis $\mathrm{B}$ virus infection and a decreased $\mathrm{HB} \mathrm{Ag}$ chronic carrier rate.

The further development of a hepatitis $B$ vaccine will be accelerated by the availability of a suitable animal model and a sensitive tissue culture assay. It is encouraging that typical HBV infection has been successfully propagated in susceptible chimpanzees (Barker et al., 1973). A sensitive tissue culture assay is not available as yet. Unlike hepatitis B immune serum globulin which should be available by 1975 , it is difficult to forecast the probable date for the availability of a safe and effective hepatitis B vaccines It is hoped that this objective will be achieved before the end of the 1970s.

\section{References}

Almeida, J.D., Rubenstein, D. \& Stott, E.J. (1971) New antigen-antibody system in Australia antigen-positive hepatitis. Lancet, ii, 1225.

Alter, H.J., Holland, P.V., Purcell, R.H., Lauder, J.J., Jemstone, S.M., Morrow, A.G. \& SChmidt, P.J. (1972) Posttransfusion hepatitis after exclusion of commercial and hepatitis B antigen-positive donors. Annals of Interna Medicine, 77, 691.

Bancroft, W.H., Mundon, F.K. \& Russell, P.K. (1972) Detection of additional antigenic determinants of hepatitis B antigen. Journal of Immunology, 109, 842.

Barker, L.F., Chisari, F.V., McGrath, P.P., Dalgard, D.W., Kirschstein, R.L., Almeida, J.D., Edgington, T.S., Sharp, D.G. \& Peterson, M.R. (1973) Transmission of type B hepatitis to chimpanzees. Journal of Infectious Diseases, 127, 648.

Blumberg, B.S., Alter, H.J. \& Visnich, S. (1965) A 'new' antigen in leukemia sera. Journal of the American Medical Association, 191, 541.

Caggiano, F. (1972) Transfusion of blood containing antiHB Ag. In: Hepatitis and Blood Transfusion (Ed. by G. N. Vyas, et al.), pp. 323-324. Grune \& Stratton.

Cherubin, E.D. \& Prince, A.M. (1971) Serum hepatitis. Specific antigen (SH) in commercial and volunteer sources of blood. Transfusion, 11, 25.

Dane, D.S., Cameron, D.H. \& Briggs, M. (1970) Virus-like particles in serum of patients with Australia-antigenassociated hepatitis. Lancet, ii, 695.

ENDERS, J.P. (1972) Introductory remarks at International Children's Centre Seminar on Viral Hepatitis. American Journal of Diseases of Children, 123, 276.

Gocke, D.J. \& PANICK, J.M. (1972) Transfusion of blood containing anti-HB Ag. In: Hepatitis and Blood Transfusion (Ed. by G. N. Vyas et al.), pp. 319-322. Grune \& Stratton. 
Havens, W.P., Jr, Ward, R., Drill, V.A. \& Paul, J.R. (1944) Proceedings of the Society of Experimental Biology and Medicine, 57, 206.

Krugman, S., Ward, R. \& Giles, J.P. (1959) Infectious hepatitis: Detection of virus during the incubation period and in clinically inapparent infection. New England Journal of Medicine, 261, 729.

Krugman, S., Ward, R. \& Giles, J.P. (1962) The natural history of infectious hepatitis. American Journal of Medicine, 32, 717 .

Krugman, S., Giles, J.P. \& Hammond, J. (1967) Infectious hepatitis: Evidence for two distinctive clinical, epidemiological and immunological types of infection. Journal of the American Medical Association, 200, 365.

Krugman, S. \& Giles, J.P. (1970) Viral hepatitis: New light on an old disease. Journal of the American Medical Association, 212, 1019.

Krugman, S., Giles, J.P. \& Hammond, J. (1971a) Viral hepatitis, type B (MS-2 strain): Studies on active immunization. Journal of the American Medical Association, 217, 41.

Krugman, S., Giles, J.P. \& Hammond, J. (1971b) Viral hepatitis, type B (MS-2 strain): Prevention with specific hepatitis B immune serum globulin. Journal of the American Medical Association, 218, 1665.

Krugman, S. \& Giles, J.P. (1973) Viral hepatitis, type B (MS-2 strain): Further observations on natural history and prevention. New England Journal of Medicine, 288, 755.

LE Bouvier, G.L. (1971) The heterogeneity of Australia antigen. Journal of Infectious Diseases, 123, 671.

Le Bouvier, G.L. (1972) Subspecificities of Australia antigen complex. American Journal of Diseases of Children, 123, 420.

MacCallum, F.O. \& Bradley, W.H. (1944) Transmission of infective hepatitis to human volunteers. Lancet, ii, 228.

Murray, R., Oliphant, J.W., Tripp, J.T., Hampil, B., Ratner, F., Diefenbach, W.C.L. \& Geller, H. (1955) Effect of ultraviolet radiation on the infectivity of ictero- genic plasma. Journal of the American Medical Association $157,8$.

Lurman, A. (1883) Eine Icterusepidemie. Klinische Wochenschrift, 22, 20.

Neefe, J.R., Stokes, J., JR \& Reinhold, J.G. (1945) Oral administration to volunteers of feces from patients with homologous serum hepatitis and infectious (epidemic) hepatitis. American Journal of Medical Science, 210, 29.

Paul, J.R., Havens, W.P., JR, SABIN, A.B. et al. (1945) Transmission experiments in serum jaundice and infectious hepatitis. Journal of the American Medical Association, 128, 911.

Prince, A.M., Szmuness, W., Woods, K.R. et al. (1971) Antibody against serum-hepatitis antigen: Prevalence and potential use as immune serum globulin in prevention of serum hepatitis infections. New England Journal of Medicine, 285, 933.

Prince, A.M. (1968) An antigen detected in the blood during the incubation period of serum hepatitis. Proceedings of the National Academy of Science, 60, 814.

Soulier, J.P., Blatix, C., Courouce, A.M., Benamon, D., Amouch, P. \& Drouet, J. (1972) Prevention of virus B hepatitis (SH hepatitis). American Journal of Diseases of Children, 123, 429.

Szmuness, W., Prince, A.M., Brotman, B. \& Hirsch, R.L. (1973) Hepatitis B antigen and antibody in blood donors: An epidemiological study. Journal of Infectious Diseases, $127,17$.

Ward, R., Krugman, S., Giles, J.P., Jacobs, A.M. \& BoDANSKY, O. (1958) Infectious hepatitis: Studies of its natural history and prevention. New England Journal of Medicine, 258, 407.

World Health Organization (1973) Technical report series, No. 512.

ZuCKeRMAN, A.J. (1971) Current studies of hepatitis type B infection. In: International congress series no. 252 on haemophilia, pp. 118-135, Excerpta Medica, Amsterdam.

ZuCKerman, A.J. (1972) Hepatitis-associated Antigen and Viruses. North Holland Publishing Co., Amsterdam.

\section{Discussion}

In answer to the question from Professor Daniel Alagille of Paris, Professor Krugman stated that he had no experience in using specific immunoglobulin with a high concentration of antibody to hepatitis B antigen to treat hepatitis B infection. Just as gammaglobulin is worthless in measles once the disease is established, it is unlikely to influence hepatitis. Controlled trials are, however, in progress in the USA to compare the role of hyperimmune gammaglobulin with standard gammaglobulin in fulminant hepatitis. Gammaglobulin given within $4 \mathrm{hr}$ of test inoculation of hepatitis $\mathbf{B}$ antigen-containing serum, was protective, antibody appeared in the serum within $3 \mathrm{hr}$. It might be possible to give such antibody for up to 1 week after inoculation and still be protected from antigenaemia. There was good reason for thinking that hyperimmune gammaglobulin would be protective for 'needle prick' exposure but larger volumes of hepatitis B antigen in blood may be a greater challenge.

Dr B. Gans, Lewisham, enquired what happened when patients were exposed to both hepatitis A and hepatitis B. Professor Krugman replied that the original serum pool had in fact contained both $\mathrm{A}$ and $B$ and in most instances, infection occurred in response to hepatitis A only; occasionally, however, hepatitis $\mathbf{A}$ infection was followed 1-2 months later by hepatitis $\mathrm{B}$ infection. 